\title{
Considering Glass Ceiling in Turkey: Ideas of Executives in Education Sector Regarding Women in the Workplace
}

\author{
Evren AYRANCI \\ (Corresponding author) \\ Istanbul AREL University \\ Tepekent - Buyukcekmece Istanbul TURKEY \\ E-mail: xonox@mynet.com \\ Tamer GÜRBÜZ \\ Management Department, \\ Orhan Gazi High School
}

Business Administration (in English) Department,

Faculty of Economics and Administrative Sciences

Turkoba Mahallesi Erguvan Sokak No: 26 / K 34537

Fevzi Cakmak Mah. 11. Sok. No: 3 Bagcilar Istanbul TURKEY

E-mail: tamer_gurbuz34@mynet.com

Accepted: October 25, 2012 Published: November 18, 2012

Doi:10.5296/ijhrs.v2i4.2583 URL: http://dx.doi.org/10.5296/ijhrs.v2i4.2583 


\begin{abstract}
The purpose of this study is to determine, taking the "glass ceiling" into account, which factors contribute to the ideas of top education executives regarding women in the workplace and to identify whether these ideas vary depending on the executives' demographic profile. This research included top state high school executives from Istanbul. An important conclusion was that the participants took into consideration only the "executive" qualities of the women in their workplace. In other words, they were already thinking about women in executive positions when participating. The participants had positive opinions regarding female executives and thoughts on the ability of female executives to create a balance between home and work. To a significant extent, these ideas varied depending on the participants' gender. When considering the participants' number of children, the ideas also generated differences. Age and marital status did not influence the participants' ideas about female executives.
\end{abstract}

Keywords: Education, executive, gender, glass ceiling, Turkey

\title{
1. Introduction
}

Today's socio-economic environment expects that people will display proper behavior according to their financial realities, and that each will, therefore, become a financial-rational person. Whatever their demographic characteristics, people are generally obligated to work and, therefore, find themselves in workplace environments. At the same time, differences in demographics and world views cause some people to encounter invisible impediments in their careers. These invisible impediments are broadly known as a "glass ceiling," and one of the main causes of the glass ceiling is gender differences.

A "glass ceiling" is a concept extensively recognized in the literature. Although this concept is utilized differently depending on the field studied, it comes up relatively seldom in reference to the field of education. Moreover, within the studies that address this subject in the context of top executives' views, the education field is rarely mentioned in the literature. This study is meant to expand the low number of studies related to the concept of a glass ceiling in the education field.

As mentioned earlier, some employees experience a series of invisible obstacles driven by gender differences in the workplace. For this study, these invisible obstacles -- known as a glass ceiling -- were taken into consideration and data were collected from top state high school executives within eight different districts of Istanbul. The purpose was to reveal the ideas of these executives about women in the workplace, and to identify how the participants' demographic features influenced these ideas. One of the conclusions reached was that the participants exposed their ideas about women in the workplace by considering them as executives. These ideas were based on positive opinions about female executives, and on the thoughts related to female executives' ability to create a home-work balance.

With respect to these factors -- positive opinions about female executives and thoughts related 
to female executives' ability to create a home-work balance -- the participants' gender drove large differences in their responses. The participants' number of children also influenced their responses. However, age and marital status did not create any differences in their ideas about female executives. Moreover, while the participants felt that female executives' sacrifices and competencies were appropriate to their executive jobs, the participants displayed a relatively more negative response with respect to female executives' ability to create a balance between work and home.

\section{The Concept of Glass Ceiling}

The term "glass ceiling" is often encountered in both the academic and the business worlds and is mentioned in various ways. According to the literature review, the glass ceiling concept was first introduced by Hymowitz and Schelhardt in 1986. As defined by these two scholars, the glass ceiling is any type of justification based on issues of race, religion, gender or sexual orientation, that prevents women (and people, in general) from promotion in their workplaces and overall in their careers. The glass ceiling, in this definition, also includes all actions based on these justifications. Noe (2010) defines it as an obstacle that prevents promotion to higher positions in businesses.

In studies from Turkey, the glass ceiling concept is also subject to different definitions. For example, The Confederation of Turkish Employer Unions describes the glass ceiling as any type of obstacle that impedes women from being promoted, especially to top management, regardless of their achievements or abilities; these obstacles are not clearly seen and are almost impossible to overcome (Turkish Confederation of Employer Associations, 2002). Aytaç (2005), on the other hand, while defining the glass ceiling as a type of arbitrary obstacle preventing women from reaching top management positions in business, also sees it as the obstacles women encounter due to the glass ceiling phenomenon and the ceiling they hit when advancing to senior positions in the business enterprise. Fettahlıoğlu and Çelik (2007) make a similar definition by considering the glass ceiling as either a barrier occurring between women and positions in top management or as an invisible and insurmountable obstacle. Whether a barrier or an obstacle, the glass ceiling prevents women from advancing regardless of their abilities and performance.

An important issue that draws attention in the literature is the emergence of a series of other concepts that are closely related to the glass ceiling. One of these concepts is "diversity management." This concept is defined, in its simplest form, as the process of steering people with different preferences and characteristics to cooperate within certain balances in the workplace environment in order to ensure the most profit for the business (Lockwood, 2005). Some of the studies dealing with this concept argue that integrating workers with different characteristics and preferences leads to a number of positive results (e.g., Friedman \& Ammo, 2002; Hitt, Tihanyi, Miller, \& Connely, 2006; Stoner \& Russell-Chapin, 1997), while others believe such integration to be harmful to the business (e.g., Okun, Fried, \& Okun, 1999). The mixed results of these studies, which cover different fields, countries and time periods, reveal 
the necessity of paying attention to the particular circumstances of members' differences when administering an enterprise.

Two other concepts related to the glass ceiling are "nepotism" and "cronyism." Each of these concepts can be defined in the shortest form as "favoritism," "preferential treatment" or "pulling strings" (Pektaş, 1999). In other words, nepotism and cronyism occur when a person is assigned to a position without his or her superiors considering factors such as skill, capacity, success or education level, but instead, using the criteria of blood relationships, friendship or citizenry (Özsemerci, 2005). "Nepotism" refers to appointments based on blood relationships, whereas those based on friendship or fellow citizen favoritism are called "cronyism" (Özsemerci, 2005).

Another concept that may be mentioned is "the pink ceiling," which is a particular type within the glass ceiling concept (Arwood, 2005). According to this concept, some people in a working environment find themselves under pressure and exclusion in their career development because of their sexual orientation -- pressure and exclusion that rise from the societal prejudices aimed at these people (Gonsiorek \& Weinrich, 1991). According to some studies (e.g., Bockting \& Cesaretti, 2001), these prejudices occur not only because of sexual orientation, but also because of religious and relational preferences.

The "glass cliff" concept may be seen as a continuation of the glass ceiling concept (Connoly, 2004). Ryan and Alsam (2007) describe the glass cliff as a form of discrimination. According to the glass cliff concept, those workers who overcome the glass ceiling obstacle -- and therefore break it -- to reach top positions, may start to face unjustified behaviors and responsibilities. In this context, it means that some employees in top management positions are given riskier and more challenging assignments than their co-workers in similar positions (Connoly, 2004). For example, Reskin and Ross (1990), who reach a conclusion supporting the glass cliff, show that female top executives are not staffed or remunerated according to the degree of their authority.

\subsection{The causes of the glass ceiling}

According to the literature, the glass ceiling encountered by women has many causes across several levels. One approach (Fettahlıoglu \& Çelik, 2007) claims that these causes are broadly divided into two particular causes: the ones created by the working women themselves and the ones stemming from environmental factors.

More detailed, up-to-date studies about the glass ceiling and its effect on women also show that that it can have various causes. These causes include (Akdöl, 2009): the presence of a male-dominated cultural organization, stereotyped attitudes towards gender, the women's inability to enter the communication webs and informal groups inside the business organization, the lack of mentorship and role models for working women, the differences perceived between men's and women's management styles, and negative attitudes towards 
women.

Table 1 includes some of these causes according to research performed by an official Turkish organization.

Table 1. The reasons for the glass ceiling impeding working women

\begin{tabular}{|ccc|}
\hline $\begin{array}{c}\text { Causes stemming from } \\
\text { individual factors }\end{array}$ & $\begin{array}{c}\text { Causes stemming from } \\
\text { organizational factors }\end{array}$ & $\begin{array}{c}\text { Causes stemming from } \\
\text { social factors }\end{array}$ \\
\hline Assuming multiple roles & Cultural organization & Professional segregation \\
\hline $\begin{array}{c}\text { Women's personal choices } \\
\text { and perceptions }\end{array}$ & The organization's politics & $\begin{array}{c}\text { Stereotyped preconceptions } \\
\text { associated with gender }\end{array}$ \\
\hline \multicolumn{3}{c}{ Lack of mentorship } \\
\hline & $\begin{array}{c}\text { Inability to access to informal } \\
\text { communication webs }\end{array}$ \\
\hline
\end{tabular}

Source: General Directorate on the Status and Problems of Women (1998). IV. Dünya Kadın Konferansı Sonuçlarının Uygulanması ve İlenmesine İlişkin Ulusal Eylem Planı [The national action plan to perform and monitor the results of IV. World Woman Conference]. Ankara, Turkey: General Directorate on the Status and Problems of Women Publications.

A literature review reveals that most explanations for the glass ceiling refer to others' perceptions that hiring females as administrators is disadvantageous. One such study is that by Tomaskovic-Devey (1993). This study reveals that during recruitment, though the candidates' knowledge and experience are taken into account, other aspects -- such gender and race -- may be considered as well. Another conclusion in this study is that males are favored in terms of recruitment.

When considering promotion inside the business, scholars who deal with gender differences, such as Ruderman, Ohlott, Panzer, and King (1999) or McDonald and Hite (1998), conclude that males are more likely to be promoted. The reason for this conclusion is the belief that males are more professional and that their managing skills are stronger. A similar result was reached by Morrison, White, and Van Velsor (1994), who argue that male workers are evaluated mostly according to their personal features and achievements, while for females, the negative perceptions of their gender intervenes.

According to some studies (e.g., Buzzanell, 1995), the notion of "discrimination" represents one of the reasons for a glass ceiling. Discrimination reveals itself in matters such as different remuneration or position even when the employees are equivalent in terms of attributions or efficiency. To describe discrimination another way, it would be a situation where the result of a behavior towards one person or a group is not equivalent to the result of the same behavior in relation to some other person or group, because of age, race, color, nationality or ethnic origin, gender, pregnancy, marital status, handicap, sexual orientation or some other personal feature (Topbaş, 2003). When analyzed as a cause for the glass ceiling, sexual discrimination 
becomes one of the most striking types of discrimination. Sexual discrimination can be expressed as a person's behavior towards a man or woman based on gender, which is more negative or less positive than the same person's behavior toward the other sex, and/or as discriminative effects of actions taken, which look to be fair, upon a man or woman (Ağca \& Yalçın, 2009). From a female perspective, sexual discrimination represents any segregation, privation or constraint that is gender related and that annihilates or impedes the ability to know, use or benefit from gender impartiality in political, economic, cultural, marital and other human rights or basic freedoms (Tuskan, 2007).

In a study conducted by Catalyst and Opportunity Now (2000), female top executives were asked what type of difficulties they have encountered in their careers. Almost $85 \%$ of the participants stated that their biggest complaint was regarding the obstacles they have faced because of their gender. In a similar manner, Catalyst (2002) conducted a study in 20 European states about the problems female top executives have encountered in large business organizations. More than half of the participants believe that the problems that occur are predominantly caused by gender.

Within the literature review, Heilman's (1995) study on negative attitudes directed to female workers is striking, and the scholar puts forward the "lack of fit" model. Executives --during recruitment or at promotion -- have various expectations related to work from candidates and employees. Attributes like ambition, success, focus and skill are mostly expected from men; assessing women as not being able to deliver on such expectations or, in other words, not being fit to do the job, may cause the glass ceiling.

As mentioned before, a prominent reason for the glass ceiling is preconceptions based on gender. Also some mental processes create preconceptions and attitudes related to the concept of "stereotyping." Stereotyping creates incomplete or incorrect perceptions about other people and may lead to placing people in undeserved social (or official) positions within a community or a group. Moreover, due to this phenomenon, people, rather than showing an effort to understand the other, assume clichés as a fact or accept ready-made judgments (Schneider, 1996). Stereotyping is not only negative, but it can also lead to positive judgments. However, the negative potential stems from not evaluating people exposed to stereotyping well enough (Schneider, 1996). The judgments directed at women in a workplace environment and the stereotyping that they face may be based on gender, and this stereotyping may be caused by the business organization's employees or managers, the organizational culture, or even the country's culture (Elmuti, Lehman, Harmon, \& Lu, 2003).

When dealing with issues such as management and promotion in a working environment, the studies within the literature often address two main subjects: the qualities of an ideal executive and the stereotyping of women in the workplace. Most of the studies regarding the ideal executive's qualities reveal results that include male characteristics. For example, the study of Schein, Mueller, Lituchy, and Liu (1998) approaches management science students from Japan and China and asks about the qualities of an ideal executive. The results show 
that executives, particularly mid-level executives, should have qualities that are generally considered masculine. What is striking in this study is that female students generally assert the same idea, though not as strongly as male students. Willemsen (2004) asks a series of management studies students from Holland about the qualities of an ideal executive. The results, grouped as male, female and neutral qualities, show that most of the qualities chosen are neutral characteristics, and the second most chosen are male. Antal and Izraeli (1993) analyze the female executive issue on an international scale. They affirm that one of the most important problems -- even in the developed countries -- is that even female executives associate leadership with being male. In a similar study, Izraeli and Adler (1994) reveal that executive features are stereotyped differently in different cultures, but these different features are generally male (ambition, combativeness, rigorousness, etc.).

Heilman, Block, Martell, and Simon (1989) study stereotyping of women in the workplace environment. When asked about the attitudes regarding female executives, the study reveals the existence of a clichéd perception of male executives towards female executives, citing qualities such as weak analytic sense, emotional instability or weaker leadership skills. Owen and Todor (1993) ask human resource management and business management students about their views of female executives. Their result shows that human resource management students show a more positive attitude towards female executives' skills; however; the results still expose the presence of stereotyping regarding female executives.

Research conducted by the United States of America Federal Glass Ceiling Commission (1995) reveals stereotyping of female workers. The study reveals beliefs that female employees cannot compete because their work commitment is less than that of male employees, that they are unable to comply with long working hours, and that they are more stressed. The report identifies such clichéd beliefs as forming a glass ceiling that holds back female employees.

In a similar manner, research conducted by Catalyst (2006) in Europe addresses how gender differences influence perception with respect to issues of management and leadership. This research includes the 50 business organizations with the highest market values in Europe, as designated by the European Commission, and reveals different perceptions regarding male and female executives. While women are perceived as more supportive and cooperative, men are seen as more focused on work and performance. Women are thought to posses more power to influence the male top management. Men are perceived to be better at problem solving. In short, in the workplace environment, men are stereotyped as "go-getters" while women are "caretakers." The study uses business organizations from different European countries and approaches culture as a variable; it reveals that, except for minor differences, the stereotyping does not change across cultures.

Considering all these points, it can be asserted that there exists a general preconception that men are more suitable managers than women. This preconception shows that, when it comes to attitudes regarding matters such as promotion and management, women receive less 
assistance than men. For example, Lockwood (2004) reaches the conclusion that businesses prefer men to be mentored, which is important for promotion and experience. Marjamaa (2004) approaches the phenomenon of female executives breaking the glass ceiling through mentorship. The study shows that the female executives were not formally able to take enough advantage of mentorship and similar counseling activities from their business organizations, but were able to find mentors through their own private web of social connections. McGuire (2002) analyzes the attitude towards women breaking the glass ceiling. This result shows that even top-level executive females usually break the glass ceiling without enough support from the top-level executives' web of social connections. Ibarra (1993) is a researcher who approaches the subject in a more general manner and analyzes the access of women and minority groups to support from inside business organizations. She reaches the conclusion that women break the glass ceiling without enough help. Milliken and Martins (1996), addressing the same topic, contend that the dominant groups within the organizations are not supportive of female employees and minorities and, therefore, argue that an accommodation process should take place in order to facilitate the work of women and minorities.

The preconceptions regarding women within the workplace are, to a certain extent, connected to their social roles as well. With women's growing role in the workforce, other aspects of life have changed, such as the reorganization of tasks between husband and wife or the reassigning of responsibilities such as child care and house maintenance to family elders or hired help. Nevertheless, this evolution hasn't removed the perception of a woman's role as wife and mother (Kocacık \& Gökkaya, 2005). The perception that a woman cannot maintain both her personal and her business role is one cause of the glass ceiling (Bedük, 2005; Gediz, 2001; Kocacık \& Gökkaya, 2005).

Moreover, prejudgments directed at female employees are influential, particularly when it comes to roles related to family or to physical appearance changes, such as the belief that a pregnant woman will have to interrupt or leave her job, and thus the business will not be able to benefit properly from that woman's human capital (Kocacık \& Gökkaya, 2005; Tuna, 2009). Particularly under the pressure of male-dominated environments, the idea of women working to support their families may lead to the result of perceiving women as a spare labor force (Kaya, 2009). In short, there is an inclination to regard women primarily in respect to their family roles and then in regard their workplace environment. That is why, even when there are many possible ways for women to achieve their career objectives, they first have to face the expectations of their husbands, children and parents (Mercanlığlu, 2009).

It is pertinent to mention the studies made with respect to the topic of the glass ceiling in Turkey. Akçamete (2004) approaches the subject of male and female executives within the banking sector, the attitudes toward women being top-level executives and the glass ceiling. The participants reveal a close connection between gender and attitudes related to females being top-level executives; the conclusion reveals a more positive attitude towards men in the same positions. Another conclusion, however, shows that the participants' other features -- 
such as age, children or experience -- are not related with their attitudes towards women being top executives.

Anafarta, Sarvan, and Yapic1 (2008), in research at the accommodation companies in the province of Antalya, reach the conclusion that the perception of a glass ceiling cannot be explained with a single factor or reason, but requires a combination of factors. Even though female executives working in these accommodation companies believe their own careers and positions to be more important than factors such as marriage or children, they state that they have constantly experienced the glass ceiling problem and have been exposed to discrimination.

This study brings to attention the ideas about female workers within the education field. In a report published in February 2011 by the Turkish Republic Prime Ministry Directorate General on the Status of Women (2011), the following conclusions about women workers within the education field draw attention:

- During the academic year 2009-2010, 95\% of preschool teachers, 52\% of primary teachers and $42 \%$ of gym teachers were women. According to these numbers, except for higher education, female teachers dominate the education field.

- In spite of female teachers being predominant in the education field, except for higher education, it can be seen that the percentage of female executives is very low. Looking at the executives of the institutions within the education field mentioned above, only $9 \%$ are women.

- Within the higher education academic staff, the percentage of females among all employees is approximately 39\%, which is higher than in many other countries. However, comparing the higher education field with the percentages of the other education fields, the number of female top executives is considerably lower. For example, the percentage of women is $5 \%$ of all university rectors, and $15 \%$ of all faculty deans.

\section{Research on Top Level Executives within Secondary Education Institutions and their Ideas towards Women in the Workplace Environment}

This research was conducted in eight different districts of Istanbul: Bağcılar, Bahçelievler, Bakırköy, Bayrampaşa, Esenler, Fatih, Güngören and Sultangazi. The participants were top-level state high school executives; they were asked about their ideas regarding women in the workplace environment. The purpose of this research was to reveal what factors their ideas were based on and to identify whether various demographic features of the participants (gender, age, marital status and number of children) created a difference in these ideas. A survey was conducted with the purpose of registering the participants' ideas. For the survey's statements, two other Turkish studies were used. One of these studies developed a scale for measuring attitudes towards female executives (Berkman, 2005), while the other addressed the obstacles confronting women executives pursuing their careers (Karaca, 2007). The 
authors simplified the statements used in each of these sources and clarified some of the statements' wording. During the implementation of this survey, top-level executives from all state high schools within the aforementioned districts (a total of 200 people) were considered as the population. Due to non-participation and partial responses, the total number of the participants was 185.

\subsection{The data's statistical structure and reliability}

First, the authors had to determine the factors the participants based their ideas about women in the workplace environment. An exploratory factor analysis was applied to the data obtained from the survey, directed at this issue. According to the results, while the Kaiser-Meyer-Olkin (KMO) value was 0.916, the Bartlett test value was significant. Therefore, the data was appropriate for factor analysis. Four factors emerged regarding the participants' ideas about women in the workplace. However, one extracted factor had only one statement. Given that it is generally recommended to have at least three statements under each factor (Norman \& Streiner, 2008), this factor was removed from the research. The remaining three factors explained $52.051 \%$ of the total variance. The names given to these three factors and the factor loads of each statement to its factor are shown in Table 2.

Table 2. Factors and related factor loads with respect to ideas towards women in the workplace environment

\begin{tabular}{|c|c|c|c|}
\hline \multicolumn{4}{|c|}{ Rotated component matrix ${ }^{a}$} \\
\hline & $\begin{array}{c}\text { Positive } \\
\text { opinions about } \\
\text { female } \\
\text { executives }\end{array}$ & $\begin{array}{l}\text { Thoughts related } \\
\text { to female } \\
\text { executives' ability } \\
\text { to create a } \\
\text { home-work } \\
\text { balance }\end{array}$ & $\begin{array}{c}\text { The perception } \\
\text { difference towards } \\
\text { males and females } \\
\text { in the workplace } \\
\text { environment }\end{array}$ \\
\hline $\begin{array}{l}\text { Female executives are successful } \\
\text { in forming the school and } \\
\text { institutional culture. }\end{array}$ & .799 & & \\
\hline $\begin{array}{l}\text { Females have enough social } \\
\text { relationships to be executives. }\end{array}$ & .797 & & \\
\hline $\begin{array}{l}\text { Female executives have enough } \\
\text { organizational vision and } \\
\text { mission. }\end{array}$ & .776 & & \\
\hline $\begin{array}{l}\text { Female executives are successful } \\
\text { in forming healthy relationships } \\
\text { with their superiors and within } \\
\text { the school environment. }\end{array}$ & .725 & & \\
\hline $\begin{array}{l}\text { Females' skills are suitable for } \\
\text { executive positions. }\end{array}$ & .723 & & \\
\hline
\end{tabular}


Female executives are inclined

toward team work.

.693

Female executives are skilled at overcoming difficulties.

Gender qualities shouldn't

influence career opportunities.

Females don't have problems in making themselves accepted by

their superiors and subordinates.

Females' emotional qualities

provide an advantage for their

managerial responsibilities.

I don't think being an executive

is a 'man's job'.

I wish the top executives were

females.

Females are determined and

assertive on matters of

management.

Female executives sacrifice their family and social lives when necessary.

Having children does not impede the female executive's job.

Female executives are successful

in creating a balance between

their families and their jobs.

Female executives can carry out

home and work life together.

Female executives can be good

wives and mothers at the same

time.

Families are sympathetic with

female executives working late hours.

In management, women should

not be given as many

opportunities as men.

Women work in lower positions

despite their skills. 
Schools and institutions are

managed with a male-dominant

perception.

Female employees take more

medical permissions and days off

than males.

a. Rotation converged in 6 iterations.

When applying the reliability analysis to the statements found under the three factors in Table 2 , the statements under the factor of perception of difference towards males and females in the workplace environment had a significantly low reliability value. Accordingly, for the following stages of the research, it is considered appropriate to not take this factor into account. Table 3 contains the results related to the reliability analyses.

Table 3 . The results of the reliability analyses

\begin{tabular}{|lcc|}
\hline \multicolumn{1}{|c}{ Factor } & $\begin{array}{c}\text { Statement } \\
\text { number under } \\
\text { each factor }\end{array}$ & $\begin{array}{c}\text { The factor's } \\
\text { Cronbach alpha } \\
\text { value }\end{array}$ \\
\hline Positive opinions about female executives & 14 & 0.925 \\
\hline $\begin{array}{l}\text { Thoughts related to female executives' ability to create } \\
\text { a home-work balance }\end{array}$ & 5 & 0.845 \\
\hline $\begin{array}{l}\text { The perception of difference towards males and } \\
\text { females in the workplace environment }\end{array}$ & 4 & 0.220 \\
\hline $\begin{array}{l}\text { All statements regarding positive opinions about } \\
\text { female executives and thoughts related to female } \\
\text { executives'ability to create a home-work balance }\end{array}$ & 19 & 0.937 \\
\hline
\end{tabular}

The positive opinions about female executives factor reveals that female executives can make sacrifices for work, can be successful at creating social relationships in the workplace environment, do possess management skills, can make themselves accepted by the other employees, are competent in determining the organizational vision and the mission, and can form a cultural organization. In short, this factor emphasizes the statements regarding female executives' abilities from the perspective of their work and management responsibilities.

Table 4. The averages and the standard deviations of the factor of positive opinions about female executives and its statements

\begin{tabular}{|ccc|}
\hline Factor/Statement & Average & $\begin{array}{c}\text { Standard } \\
\text { deviation }\end{array}$ \\
\hline$\underline{\text { Positive opinions about female executives }}$ & $\underline{3.3718}$ & $\underline{.84319}$ \\
\hline Female executives have enough organizational vision and & 3.5838 & 1.15850 \\
\hline
\end{tabular}




\begin{tabular}{|l|cc|}
\hline \hline mission. & & \\
\hline $\begin{array}{l}\text { Female executives are successful in forming the school and } \\
\text { institutional culture. }\end{array}$ & 3.5730 & 1.09660 \\
\hline Females have enough social relationships to be executives. & 3.6378 & 1.11007 \\
\hline $\begin{array}{l}\text { Female executives are successful in forming healthy } \\
\text { relationships with their superiors and within the school } \\
\text { environment. }\end{array}$ & 3.4324 & 1.15015 \\
\hline Females' skills are suitable for executive positions. & 3.5568 & 1.21506 \\
\hline Female executives are skilled at overcoming difficulties. & 3.3514 & 1.12810 \\
\hline Female executives are inclined toward team work. & 3.5676 & 1.13110 \\
\hline Gender qualities shouldn't influence career opportunities. & 4.0162 & 1.13480 \\
\hline $\begin{array}{l}\text { Females don't have problems in making themselves accepted } \\
\text { by their superiors and subordinates. }\end{array}$ & 2.9784 & 1.18394 \\
\hline $\begin{array}{l}\text { Females' emotional qualities provide an advantage for their } \\
\text { managerial responsibilities. }\end{array}$ & 2.7514 & 1.25231 \\
\hline I don't think being executive is a 'man's job'. & 3.5946 & 1.43443 \\
\hline $\begin{array}{l}\text { Female executives sacrifice their family and social lives when } \\
\text { necessary. }\end{array}$ & 3.1784 & 1.15888 \\
\hline I wish the top executives were females. & 2.8162 & 1.29328 \\
\hline $\begin{array}{l}\text { Females are determined and assertive on matters of } \\
\text { management. }\end{array}$ & 3.1676 & 1.10779 \\
\hline
\end{tabular}

Table 4 shows the averages and the standard deviations of the factor of positive opinions about female executives and its respective statements. It appears that the participants generally agreed with the statements under this factor. While they mostly maintained that gender qualities shouldn't influence career opportunities, it can be seen that they were less likely to support the notion that the top executives be females or that women's emotional qualities provide an advantage for their managerial responsibilities. In general, the participants appeared to feel that it is difficult for females to make themselves accepted by superiors and subordinates in the workplace. The participants also diverged on the opinion that being an executive is not a "man's job," but were substantially uniform regarding the statement that female executives are successful in forming the school and institutional culture.

As for the thoughts related to female executives'ability to create a home-work balance factor, it states that, besides being able to carry out home and work life together and create a balance between their families and their jobs, the female executives are perceived to assume the wife and mother roles as well (Table 5).

Table 5. The averages and the standard deviations of the factor of thoughts related to female executives' ability to create a home-work balance and its statements 


\begin{tabular}{|lll|}
\hline \multicolumn{1}{|c}{ Factor/Statement } & Average & $\begin{array}{c}\text { Standard } \\
\text { deviation }\end{array}$ \\
\hline \multicolumn{1}{|c|}{ Thoughts related to female executives' ability to create a } & $\underline{2.9459}$ & $\underline{.89764}$ \\
\hline $\begin{array}{l}\text { home-work balance } \\
\text { Female executives can carry out home and work life }\end{array}$ & 3.4378 & 1.19677 \\
\hline $\begin{array}{l}\text { Having children does not impede the female executive's job. } \\
\text { Female executives are successful in creating a balance } \\
\text { between their families and their jobs. }\end{array}$ & 3.16789 & 1.19370 \\
\hline $\begin{array}{l}\text { Female executives can be good wives and mothers at the } \\
\text { same time. }\end{array}$ & 3.5514 & 1.08298 \\
\hline $\begin{array}{l}\text { Families are sympathetic with female executives working } \\
\text { late hours. }\end{array}$ & 2.0541 & .99307 \\
\hline
\end{tabular}

It is, however, revealed on Table 5 that even though the participants mostly support the idea that a female executive can also be a good wife and mother, it is clear that they did not agree that the female executives' families sympathized with their working late hours. Furthermore, the participants' thoughts showed enormous diversity on the statement that female executives can be, at the same time, a good wife and mother, but showed some uniformity on the statement regarding families sympathizing with female executives working late hours.

As mentioned before and as seen on Table 3, the perception difference towards males and females in the workplace environment factor has an unacceptably low reliability value, and so this factor has not been taken into account any further in the research. The authors argue that the cause lies within the content of the factor. The other two factors pay attention only to females' executive qualities and generally contain positive statements about their executive nature. However, the perception difference towards males and females in the workplace environment factor also takes into account females who are not executives (e.g., women work in lower positions despite their skills), and comprises statements that enclose negative elements towards women in the workplace environment (e.g., female employees take more medical permissions and days off than males; in management, women should not be given as many opportunities as men).

3.2. The relationship between the participants' demographic features and ideas towards women in the workplace environment

As seen in the previous section, the participants' ideas about women in the workplace environment are statistically based on two factors. Next, the authors explored whether there were differences between these two factors' statements given the participants' demographic features.

Specifically, the authors were concerned with whether each demographic feature of the 
participants (gender, marital status, number of children and age) cause a difference in responses for each statement of the factors. In this respect, an analysis of variance (ANOVA) was applied between each demographic feature and each statement. Before each analysis of variance, the Levene test was used to investigate whether the variances were homogeneous. Only the statistically significant relationships (according to the ANOVA results) were transferred, together with the variables with homogenous variances in Levene test results (see Table 6, Table 7 and Table 8).

One conclusion reached is that participants' gender created differences in many statements which generated positive opinions about female executives. Table 6 contains information related with this matter.

Table 6. The statistically significant results of the ANOVAs of the statements which reflect positive opinions about female executives, according to the participants' gender

\begin{tabular}{|c|c|c|c|c|c|c|}
\hline \multicolumn{7}{|c|}{ ANOVA } \\
\hline \multirow{5}{*}{$\begin{array}{l}\text { Female executives sacrifice } \\
\text { their family and social lives } \\
\text { when necessary. }\end{array}$} & & $\begin{array}{l}\text { Sum of } \\
\text { squares }\end{array}$ & df & Mean square & $\mathrm{F}$ & Sig. \\
\hline & $\begin{array}{l}\text { Between } \\
\text { groups }\end{array}$ & 5.768 & 1 & 5.768 & 4.374 & .038 \\
\hline & $\begin{array}{l}\text { Within } \\
\text { groups }\end{array}$ & 241.346 & 183 & 1.319 & & \\
\hline & Total & 247.114 & 184 & & & \\
\hline & \multicolumn{6}{|c|}{ Levene test value: .006; df1: 1 , df2: 183; Sig.: .940 } \\
\hline \multirow{4}{*}{$\begin{array}{l}\text { Females are determined and } \\
\text { assertive on matters of } \\
\text { management. }\end{array}$} & $\begin{array}{l}\text { Between } \\
\text { groups }\end{array}$ & 18.452 & 1 & 18.452 & 16.284 & .000 \\
\hline & $\begin{array}{l}\text { Within } \\
\text { groups }\end{array}$ & 207.354 & 183 & 1.133 & & \\
\hline & Total & 225.805 & 184 & & & \\
\hline & \multicolumn{6}{|c|}{ Levene test value: $1.048 ;$ df1: 1, df2: 183; Sig.: .307 } \\
\hline \multirow{4}{*}{$\begin{array}{l}\text { Female executives are skilled } \\
\text { at overcoming difficulties. }\end{array}$} & $\begin{array}{l}\text { Between } \\
\text { groups }\end{array}$ & 32.186 & 1 & 32.186 & 29.162 & .000 \\
\hline & $\begin{array}{l}\text { Within } \\
\text { groups }\end{array}$ & 201.976 & 183 & 1.104 & & \\
\hline & Total & 234.162 & 184 & & & \\
\hline & \multicolumn{6}{|c|}{ Levene test value: .334; df1: 1, df2: 183; Sig.: .564 } \\
\hline Females' emotional qualities & $\begin{array}{l}\text { Between } \\
\text { groups }\end{array}$ & 21.116 & 1 & 21.116 & 14.449 & .000 \\
\hline management responsibilities. & $\begin{array}{l}\text { Within } \\
\text { groups }\end{array}$ & 267.446 & 183 & 1.461 & & \\
\hline
\end{tabular}




\begin{tabular}{|c|c|c|c|c|c|c|}
\hline & Total & 288.562 & \multicolumn{4}{|l|}{184} \\
\hline & \multicolumn{6}{|c|}{ Levene test value: .025; df1: 1 , df2: $183 ;$ Sig.: .874 } \\
\hline \multirow{4}{*}{$\begin{array}{l}\text { Female executives are } \\
\text { inclined toward team work. }\end{array}$} & $\begin{array}{l}\text { Between } \\
\text { groups }\end{array}$ & 30.554 & 1 & 30.554 & 27.295 & .000 \\
\hline & $\begin{array}{l}\text { Within } \\
\text { groups }\end{array}$ & 204.851 & 183 & 1.119 & & \\
\hline & Total & 235.405 & 184 & & & \\
\hline & \multicolumn{6}{|c|}{ Levene test value: .002; df1: 1, df2: 183; Sig.: .961 } \\
\hline \multirow{4}{*}{$\begin{array}{l}\text { Females' skills are suitable for } \\
\text { executive positions. }\end{array}$} & $\begin{array}{l}\text { Between } \\
\text { groups }\end{array}$ & 52.816 & 1 & 52.816 & 44.166 & .000 \\
\hline & $\begin{array}{l}\text { Within } \\
\text { groups }\end{array}$ & 218.838 & 183 & 1.196 & & \\
\hline & Total & 271.654 & 184 & & & \\
\hline & \multicolumn{6}{|c|}{ Levene test value: $.407 ;$ df1: 1 , df2: 183 ; Sig.: .524 } \\
\hline \multirow{4}{*}{$\begin{array}{l}\text { Female executives have } \\
\text { enough organizational vision } \\
\text { and mission. }\end{array}$} & $\begin{array}{l}\text { Between } \\
\text { groups }\end{array}$ & 37.846 & 1 & 37.846 & 33.121 & .000 \\
\hline & $\begin{array}{l}\text { Within } \\
\text { groups }\end{array}$ & 209.105 & 183 & 1.143 & & \\
\hline & Total & 246.951 & 184 & & & \\
\hline & \multicolumn{6}{|c|}{ Levene test value: .014; df1: 1, df2: 183; Sig.: .907 } \\
\hline \multirow{4}{*}{$\begin{array}{l}\text { Female executives are } \\
\text { successful in forming the } \\
\text { school and institutional } \\
\text { culture. }\end{array}$} & $\begin{array}{l}\text { Between } \\
\text { groups }\end{array}$ & 18.919 & 1 & 18.919 & 17.111 & .000 \\
\hline & $\begin{array}{l}\text { Within } \\
\text { groups }\end{array}$ & 202.346 & 183 & 1.106 & & \\
\hline & Total & 221.265 & 184 & & & \\
\hline & \multicolumn{6}{|c|}{ Levene test value: .456 ; df1: 1 , df2: 183 ; Sig.: .500} \\
\hline \multirow{4}{*}{$\begin{array}{l}\text { Females have enough social } \\
\text { relationships to be executives. }\end{array}$} & $\begin{array}{l}\text { Between } \\
\text { groups }\end{array}$ & 28.164 & 1 & 28.164 & 25.955 & .000 \\
\hline & $\begin{array}{l}\text { Within } \\
\text { groups }\end{array}$ & 198.571 & 183 & 1.085 & & \\
\hline & Total & 226.735 & 184 & & & \\
\hline & \multicolumn{6}{|c|}{ Levene test value: .241; df1: 1, df2: 183; Sig.: .624 } \\
\hline \multirow{3}{*}{$\begin{array}{l}\text { I don't think being an } \\
\text { executive is a 'man's job'. }\end{array}$} & $\begin{array}{l}\text { Between } \\
\text { groups }\end{array}$ & 51.613 & 1 & 51.613 & 28.886 & .000 \\
\hline & $\begin{array}{l}\text { Within } \\
\text { groups }\end{array}$ & 326.982 & 183 & 1.787 & & \\
\hline & Total & 378.595 & 184 & & & \\
\hline
\end{tabular}


Levene test value: .923; df1: 1, df2: 183; Sig.: .338

According to Table 6, the participants' gender creates differences regarding an important aspect of their positive opinions about female executives. While the aforementioned opinions are based on a total of 14 statements, 10 of these statements differ depending on the participants' gender. To be more specific, the participants' opinions are: female executives can make sacrifices for work; they possess assertiveness, skill, organizational vision and mission; they are suitable for the executive position when it comes to their ability to form an institutional culture, their social relationships, their fit and their ability to work in a team. Differences appear in responses to these statements according to the participants' gender.

In a similar manner, differences based on the participants' gender also come up in some statements regarding thoughts related to female executives' ability to create a work-home balance. Table 7 displays the relevant results of the analysis of variance data. According to this table, the participants' gender causes a difference in the thoughts about female executives' ability to be effective both at home and in the workplace environment, and the ability to simultaneously perform the role of executive and that of wife and mother.

Table 7. The statistically significant results of the ANOVAs of the statements regarding thoughts about female executives' ability to create a home-work balance, according to the participants' gender

\begin{tabular}{|c|c|c|c|c|c|c|}
\hline \multicolumn{7}{|c|}{ ANOVA } \\
\hline \multirow{5}{*}{$\begin{array}{l}\text { Female executives can carry } \\
\text { out home and work life } \\
\text { together. }\end{array}$} & & $\begin{array}{l}\text { Sum of } \\
\text { squares }\end{array}$ & df & Mean square & $\mathrm{F}$ & Sig. \\
\hline & $\begin{array}{c}\text { Between } \\
\text { groups }\end{array}$ & 16.605 & 1 & 16.605 & 12.306 & .001 \\
\hline & $\begin{array}{l}\text { Within } \\
\text { groups }\end{array}$ & 246.930 & 183 & 1.349 & & \\
\hline & Total & 263.535 & 184 & & & \\
\hline & \multicolumn{6}{|c|}{ Levene test value: 1.404 ; df1: 1 , df2: 183 ; Sig.: .238 } \\
\hline \multirow{4}{*}{$\begin{array}{l}\text { Female executives can be } \\
\text { good wives and mothers at the } \\
\text { same time. }\end{array}$} & $\begin{array}{c}\text { Between } \\
\text { groups }\end{array}$ & 11.311 & 1 & 11.311 & 7.768 & .006 \\
\hline & $\begin{array}{l}\text { Within } \\
\text { groups }\end{array}$ & 266.451 & 183 & 1.456 & & \\
\hline & Total & 277.762 & 184 & & & \\
\hline & \multicolumn{6}{|c|}{ Levene test value: .190; df1: 1, df2: 183; Sig.: .664 } \\
\hline
\end{tabular}

To summarize, when looking at Tables 6 and 7, it can be seen that the participants' gender creates significant variation in ideas regarding female executives. Conversely, looking at 
another demographic characteristic -- participant's age -- and applying the Levene (homogeneity of variances) and ANOVA tests, it is revealed that there is no difference either with the statements reflecting positive opinions about female executives, or with those thoughts regarding female executives being able to create a home-work balance. A similar result is found when evaluating the participants' marital status.

In contrast to the results reached when looking at age and marital status, taking the participants' number of children into account once again creates differences in the responses. Table 8 contains the statements under each of the two factors, showing statistically relevant differences according to the participants' number of children.

Table 8. The statistically significant results of the ANOVAs of the statements related to the positive opinions towards female executives and the thoughts about their ability to create a home-work balance, according to the participants' number of children

\begin{tabular}{|c|c|c|c|c|c|}
\hline \multicolumn{6}{|c|}{ ANOVA } \\
\hline \multicolumn{6}{|c|}{$\begin{array}{l}\text { Those statements that reflect the participants' positive opinions -- according to their } \\
\text { number of children -- towards female executives and show statistically significant difference. }\end{array}$} \\
\hline \multirow{5}{*}{\begin{tabular}{lcc} 
Females' & \multicolumn{2}{c}{ emotional } \\
qualities & provide & an \\
advantage & for their \\
managerial & responsibilities.
\end{tabular}} & $\begin{array}{l}\text { Sum of } \\
\text { squares }\end{array}$ & df & Mean square & $\mathrm{F}$ & Sig. \\
\hline & 15.026 & 3 & 5.009 & 3.314 & .021 \\
\hline & 273.536 & 181 & 1.511 & & \\
\hline & 288.562 & 184 & & & \\
\hline & \multicolumn{5}{|c|}{ Levene test value: .744; df1: 3 , df2: 181; Sig.: .527 } \\
\hline \multirow{4}{*}{$\begin{array}{l}\text { Females' skills are suitable } \\
\text { for executive positions. }\end{array}$} & 16.878 & 3 & 5.626 & 3.997 & .009 \\
\hline & 254.776 & 181 & 1.408 & & \\
\hline & 271.654 & 184 & & & \\
\hline & \multicolumn{5}{|c|}{ Levene test value: .153; df1: 3 , df2: 181; Sig.: .928 } \\
\hline \multicolumn{6}{|c|}{ ANOVA } \\
\hline \multicolumn{6}{|c|}{$\begin{array}{l}\text { Those statements that reflect the participants' thoughts -- according to their number } \\
\text { of children -- about female executives being able to create a home-work balance and show } \\
\text { statistically significant difference. }\end{array}$} \\
\hline $\begin{array}{l}\text { Female executives are } \\
\text { successful in creating a }\end{array}$ & $\begin{array}{l}\text { Sum of } \\
\text { squares }\end{array}$ & df & Mean square & $\mathrm{F}$ & Sig. \\
\hline
\end{tabular}




\begin{tabular}{|c|c|c|c|c|c|c|}
\hline \multirow[t]{4}{*}{$\begin{array}{l}\text { balance between their } \\
\text { families and their jobs. }\end{array}$} & $\begin{array}{l}\text { Between } \\
\text { groups }\end{array}$ & 10.653 & 3 & 3.551 & 3.133 & .027 \\
\hline & $\begin{array}{l}\text { Within } \\
\text { groups }\end{array}$ & 205.152 & 181 & 1.133 & & \\
\hline & Total & 215.805 & 184 & & & \\
\hline & \multicolumn{6}{|c|}{ Levene test value: .725; df1: 3, df2: 181; Sig.: .538 } \\
\hline \multirow{4}{*}{$\begin{array}{l}\text { Female executives can be } \\
\text { good wives and mothers at } \\
\text { the same time. }\end{array}$} & $\begin{array}{l}\text { Between } \\
\text { groups }\end{array}$ & 12.400 & 3 & 4.133 & 2.819 & .040 \\
\hline & $\begin{array}{l}\text { Within } \\
\text { groups }\end{array}$ & 265.362 & 181 & 1.466 & & \\
\hline & Total & 277.762 & 184 & & & \\
\hline & \multicolumn{6}{|c|}{ Levene test value: 1.597 ; df1: 3 , df2: 181; Sig.: .192 } \\
\hline
\end{tabular}

In Table 8, the participants show differences regarding opinions related to female executives' emotional features and abilities, depending on their own number of children. A similar result can also be seen with respect to female executives creating a home-work balance and with respect to their ability to perform different roles.

\section{Conclusion}

This study addresses ideas regarding issues such as female executives' presence in the workplace environment, their work and their management of responsibilities while taking into account the glass ceiling concept. It analyses the factors these ideas are based on and whether the statements related to these factors show differences according to the participants' demographic features.

As one of the results revealed, the participants stated their ideas by considering the qualities and skills of women for executive positions. In other words, all the factors that came out -based on the participants' ideas -- predominantly regarded the females' executive qualities. If one considers that the study addresses the glass ceiling concept and that it focuses on female executives, it can be said that the factors revealed, which incline towards the women's quality of being an executive, are within the expectation limits.

According to another result, the participants' gender generated differences between ideas related to female executives. Ten out of fourteen statements regarding the positive opinions directed toward female executives displayed differences according to the participants' gender. As mentioned before, these ten statements were inclined towards women being competent for the executive job. Therefore the participants -- according to their own gender -- had different beliefs regarding women executives' competence. In a similar manner, considering the thoughts regarding female executives balancing work and home life and performing different roles, the participants' responses again showed differences depending on their gender. The result of gender creating significant differences between the participants' ideas is similar to 
results seen in the literature review. As pointed out earlier, according to the literature review, one of the causes of the glass ceiling is the preconception that women are not competent on matters of managing and finishing tasks. Moreover, some studies go so far as to claim that women are, in fact, divided between home and work responsibilities, are forced to assume many different roles and consequently, are not able to dedicate themselves to the workplace environment. This research concludes that the statements which show difference between genders are basically analogous with the claims and conclusions found within the literature review.

In contrast to the participants' gender, their age and marital status did not generate any differences in thoughts towards female executives creating a home-work balance. One of the authors' expectations was that marital status, in particular, would create a difference in these thoughts. To be more specific, depending on whether the participants were married, single or widowers, it was expected that they would have different thoughts regarding themselves or their spouses performing different roles simultaneously at home and at work, and consequently, regarding their ability to create a home-work balance. However, as mentioned, the results of the research did not meet this expectation.

A striking result is seen when the participants' own number of children was considered. With respect to this feature, differences occurred regarding the thoughts about female executives creating a home-work balance and performing different roles. Therefore, it may be assumed that the female executives' role as mother is considered more important than that as wife. The opinions related to the female executives' emotional advantages and the necessary skills for the executive job also differed according to the participants' number of children. This difference may have various causes. The participants may have thought that taking care of their own children is a serious responsibility and, therefore, that women, carrying out similar childcare responsibilities would behave equally responsibly regarding executive matters. From another point of view, the participants, thinking of themselves or their spouses, may believe that women who perform the mother role are stronger from an emotional perspective; this belief may carry over into the workplace environment.

In summation, the study reveals the opinions of top state high school executives regarding women's presence in the workplace. These beliefs are based on two factors and the study reveals that they are directed only towards the executive qualities of women. The participants' gender created substantial differences when it came to positive opinions about female executives and the thoughts about their ability to create a home-work balance; the participants' number of children, in contrast, created only a small difference in the same opinions and thoughts. The other demographic features (marital status and age) did not bring forth any differences.

As mentioned before, the positive opinions towards the notion of female executives contain statements of positive quality related to women's competencies and sacrifices. Another conclusion reached was that the participants agreed with these positive qualities. In 
consequence, they thought that female executives, from the perspective of their jobs, are both capable and devoted. Nevertheless, the participants approached the issue of female executives being able to create a balance between home and work with a bit more hesitation.

This study concludes that people in top-level executive positions from the secondary education field have positive ideas about female executives. Likewise, it reveals that differences in these ideas appear according to the surveyed executives' demographic features, and, in particular, their gender. It is clear that women encounter difficulties in the workplace environment; therefore, more research should be done regarding the invisible barriers they must face. Such research would be an important contribution to the national and international literature on the glass ceiling.

\section{References}

Ağca, A., \& Yalçın, N. (2009). Muhasebe mesleğinde kadın olmak sorun teşkil eder mi? [Is it a problem to be a woman in the profession of accounting?]. Dumlupınar Üniversitesi Sosyal Bilimler Dergisi [Dumlupınar University Journal of Social Sciences]. 24. 37-46.

Akçamete, C. (2004). Kadın ve erkek yöneticilerin kadınların üst düzey yönetici olmalarına yönelik tutumlarının ve cam tavan sorununun incelenmesi: Bankalarda bir örnek uygulama [Examining the attitudes of men and women managers related with the issue of women becoming top level managers and the glass ceiling problem: Practice in the banking sector]. (Master's thesis). Hacettepe University, Ankara, Turkey.

Akdöl, B. (2009). Cam tavan ve kurumsal bir strateji pozitif ayrımcılık; ilaç sektöründe bir siniflandırma [Glass ceiling and a corporate strategy affirmative action; a typology in the sector of medicine]. (Master's thesis). İstanbul University, İstanbul, Turkey.

Anafarta, N., Sarvan, F., \& Yapıcı, N. (2008). Konaklama işletmelerinde kadın yöneticilerin cam tavan algısı: Antalya ilinde bir araştırma [The glass ceiling perceptions of female managers in hospitality sector: A research in the city of Antalya]. Akdeniz I.I.B.F. Dergisi [Akdeniz I.I.B.F. Journal]. 15. 111-137.

Antal, A. B., \& Izraeli, D. N. (1993). A global comparison of women in management: Women managers in their homelands and as expatriates. In H. J. Muller \& M. Rowel (Eds.), Women in management: Trends, issues, and challenges in managerial diversity (pp. 52-97). Newbury Park, CA: Sage Publications.

Arwood, T. (2005). Sexual orientation and leadership: The pink ceiling. (Doctoral dissertation). Spalding University, Louisville, KY, USA.

Aytaç, S. (2005). Çalışma yaşamında kariyer [Career in work life]. Bursa, Turkey: Ezgi Publications. 
Bedük, A. (2005). Türkiye'de çalışan kadın ve kadın girişimciliği [Working females in Turkey and the entrepreneurship of females]. Elektronik Sosyal Bilimler Dergisi [Electronic Journal of Social Sciences]. 3. 106-117.

Berkman, Y. (2005). Attitudes towards women managers: Development of a new measure. (Master's thesis). Koç University, İstanbul, Turkey.

Bockting, W. O., \& Cesaretti, C. (2001). Spirituality, transgender identity and coming out. Journal of Sex Education and Therapy. 26. 291-300.

Buzzanell, P. M. (1995). Reframing the glass ceiling as a socially constructed process: Implications for understanding and change. Communication Monographs. 62. 327-354.

Catalyst. (2002). Women in leadership: A European business imperative. [Online] Available: http://www.catalyst.org/file/51/women\%20in\%20leadership\%20a\%20european $\% 20$ business\%20imperative.pdf

Catalyst. (2006). Different cultures, similar perceptions: Stereotyping of western European business leaders. [Online] Available: http://www.catalyst.org/file/42/ different $\% 20$ cultures, $\% 20$ similar\%20perceptions $\% 20$ stereotyping $\% 20$ of $\% 20$ western $\% 20$ eur opean $\% 20$ business $\% 20$ leaders.pdf

Catalyst and Opportunity Now. (2000). Breaking the barriers: Women in senior management in the UK. [Online] Available: http://www.catalyst.org/file/41/breaking\%20the\% 20barriers\%20women\%20in\%20senior\%20management\%20in\%20the\%20u.k.pdf

Connoly, J. (2004, September 28). Real transparency will break the glass ceiling. [Online] Available:

http://www.personneltoday.com/Articles/28/09/2004/25801/Real-transparency-will-break-the -glass-ceiling.htm

Elmuti, D., Lehman, J., Harmon, B., \& Lu, X. (2003). Inequality between genders in the executive suite in corporate America: Moral and ethical issues. Equal Opportunities International. 22. 40-59.

Fettahlıoğlu, O. Ö., \& Çelik, A. (2007). Kariyer yönetiminde güncel bir kavram olarak cam tavan sendromu ve kadın yöneticiler boyutu [Glass ceiling syndrome as a current concept in career management and the dimension of female managers]. In M. Ş. Şimşek, A. Çelik, \& A. Akatay (Eds.), Kariyer yönetimi ve insan kaynaklarl yönetimi uygulamalar [Career management and human resources management applications] ( $2^{\text {nd }}$ ed., pp. 239-256). Ankara, Turkey: Gazi Publications.

Friedman, H. H., \& Ammo, T. (2002). Workplace diversity: The key to survival and growth. [Online] Available: http://www.westga.edu/ bquest/2002/diversity.htm 
Gediz, D. G. (2001). Çalışma yaşamında bayan olmak [Being a female in work life]. Turkish Journal of Occupational Health and Safety. 5. 27-30.

General Directorate on the Status and Problems of Women. (1998). IV. Dünya Kadın Konferansı Sonuçlarının Uygulanması ve İlenmesine Illişkin Ulusal Eylem Planı [The national action plan to perform and monitor the results of IV. World Woman Conference]. Ankara, Turkey: General Directorate on the Status and Problems of Women Publications.

Gonsiorek, J. C, \& Weinrich, J. D. (1991). The definition and scope of sexual orientation. In J. C. Gonsiorek \& J. D. Weinrich (Eds.), Homosexuality: Research implications for public policy (pp. 1-12). Newbury Park, CA: Sage.

Heilman, M. E. (1995). Sex stereotypes and their effects in the workplace: What we know and what we don't know. Journal of Social Behavior and Personality. 10. 3-26.

Heilman, M. E., Block, C., Martell, R., \& Simon, M. (1989). Has anything changed? Current characterizations of males, females and managers. Journal of Applied Psychology. 74. 935-942.

Hitt, M. A., Tihanyi, L., Miller, T., \& Connely, B. (2006). International diversification: Antecedents, outcomes, and moderators. Journal of Management. 32. 831-867.

Hymowitz, C., \& Schellhardt, T. D. (1986, March 24). The glass ceiling: Why women can't seem to break the invisible barrier that blocks them from the top jobs. The Wall Street Journal, Section 4, pp. 4-5.

Ibarra, H. (1993). Personal networks of women and minorities in management: A conceptual framework. Academy of Management Review. 18. 56-87.

Izraeli, D. N., \& Adler, N. (1994). Competitive frontiers: Women managers in a global economy. In N. Adler \& D. Izraeli (Eds.), Competitive frontiers: Women managers in a global economy (pp. 3-21). Cambridge, MA: Blackwell.

Karaca, A. (2007). Kadın yöneticilerde kariyer engelleri: Cam tavan sendromu üzerine uygulamalı bir araştırma [Career blocks for female managers: An applied research on glass ceiling syndrome]. (Master's thesis). Selçuk University, Konya, Turkey.

Kaya, S. (2009, January). Bayan işgücünün genel profili ve çalışma yaşamında karşılaştı̆̆ 1 sorunlar (II) [The general profile of female workforce and the problems it faces in work life (II)]. İzmir Ticaret Odası Sektörel Ar\&Ge Bülteni [Izmir Chamber of Trade Sectoral R\&D Bulletin], pp. 29-35.

Kocacık, F., \& Gökkaya, V. B. (2005). Türkiye'de çalışan kadın ve sorunları [Working 
woman in Turkey and her problems]. Cumhuriyet Üniversitesi İtisadi ve İdari Bilimler Dergisi [Cumhuriyet University Journal of Economics and Administrative Sciences]. 6. 195-219.

Lockwood, N. R. (2004). The glass ceiling: Domestic and international perspectives. HR Magazine. 49. 1-10.

Lockwood, N. R. (2005). Workplace diversity: Leveraging the power of difference for competitive advantage. HR Magazine. 50. 1-11.

Marjamaa, L. (2004). Moving on up. AFP Exchange, 24, 58-61.

McDonald, K. S., \& Hite, L. M. (1998). Human resource development's role in women's career progress. New Directions for Adult and Continuing Education. 80. 53-62.

McGuire, G. M. (2002). Gender, race and the shadow structure: A study of informal networks inequality in a work organization. Gender \& Society. 16. 303-304.

Mercanlığlu, Ç. (2009). Cinsiyete dayalı eşitsizlik; kadın yöneticilerin iş ve özel hayatlarını dengeleme zorluklarl ve bedelleri [Inequality based on gender; the hardnesses and the costs of balancing work and private lives of female managers]. Proceedings of the Conference of International - Eclectic Studies about Women (pp. 35-44). Sakarya University, Sakarya, Turkey.

Milliken, F. J., \& Martins, L. L. (1996). Searching for common threads: Understanding the multiple effects of diversity in organizational groups. Academy of Management Review. 21. 402-433.

Morrison, A. M., White, R. P., \& Van Velsor, E. (1994). Breaking the glass ceiling: Can women reach the top of America's largest corporations? Cambridge, MA: Perseus Publishing.

Noe, R. A. (2010). Insan kaynaklarının eğitimi ve geliştirilmesi [Employee training and development]. (C. Çetin, Trans.). İstanbul, Turkey: Beta Publications.

Norman, G. R., \& Streiner, D. L. (2008). Biostatistics: The bare essentials (3rd ed.). Ontario, Canada: BC Decker Inc.

Okun, B. F., Fried, J., \& Okun, M. L. (1999). Understanding diversity: A-learning-as-practice- primer. Pacific Grove, CA: Brooks/Cole Publishing.

Owen, C. L., \& Todor, W. D. (1993). Attitudes toward women as managers: Still the same few women hold executive positions. [Online] Available: http://findarticles.com/ 
p/articles/mi_m1038/is_n2_v36/ai_13815059/pg_1

Özsemerci, K. (2005). Türk kamu yönetiminde yolsuzluklar, nedenleri, zararları ve çözüm önerileri [Malpractices in Turkish public management, reasons, harms and solution advices]. Retrieved from http://www.turkhukuksitesi.com/makale_206.htm

Pektaş, E. K. (1999). Büyük kent belediyelerinin eğitim ve kültür hizmetlerine siyasal parti ideolojilerinin yansıması [The reflections of political party ideologies on the education and cultural services of major city municipalities]. [Online] Available: http://www.ekitapyayin.com/id/027/

Reskin, B. F., \& Ross, P. A. (1990). Job queues, gender queues: Explaining women's inroads into male occupations. Philadelphia, PA: Temple University Press.

Ruderman, M. N., Ohlott, P. J., Panzer, K., \& King, S. N. (1999). How managers view success: Perspectives of high-achieving women. Leadership in Action. 18. 6-10.

Ryan, M. K., \& Alsam, S. A. (2007). The glass cliff: Exploring the dynamics surrounding the appointment of women to precarious leadership positions. Academy of Management Review. 32. 549-572.

Schein, V. E., Mueller, R., Lituchy, T., \& Liu, J. (1998). Think manager-think male: A global phenomenon? Journal of Organizational Behavior. 17. 33-41.

Schneider, D. J. (1996). Modern stereotype research: Unfinished business. In C. N. Macrae, C. Stangor, \& M. Hewstone (Eds.), Stereotypes and stereotyping (pp. 419-465). New York: The Guilford Press.

Stoner, C. R., \& Russell-Chapin, L. A. (1997). Creating a culture of diversity management: Moving from awareness to action. Business Forum. 22. 6-12.

Tomaskovic-Devey, D. (1993). Gender and racial inequality at work: The sources and consequences of job segregation. Ithaca, NY: ILR Press.

Topbaş, F. (2003). Emek piyasalarında cinsiyete dayalı ücret ayrımcılı̆̆l ve Türkiye örneği [Renumeration discrimination based on gender and an example in Turkey. (Unpublished expert thesis). Karadeniz Technical University, Trabzon, Turkey.

Tuna, Y. (2009). Çalısan hamile bayanların sorunlart ve beklentileri üzerine Araştırma [A research on the problems and expectations of working pregnant women]. Proceedings of the Conference of International - Eclectic Studies about Women (pp. 214-224). Sakarya University, Sakarya, Turkey.

Turkish Confederation of Employer Associations. (2002). Çağdaş İş merkezlerinde kadın 


\section{Macrothink

işgücünün konumu: Bursa örneği [The situation of women workforce in contemporary workcenters: The example of Bursa]. [Online] Available: http://www.tisk.org.tr/yayinlar.asp?sbj=ana\&ana_id=22

Turkish Republic Prime Ministry Directorate General on the Status of Women (2011). Türkiye'de kadının durumu [The situation of woman in Turkey]. [Online] Available: http://www.feminkurd.net/admin/resources/files/belgeler/trde_kadinin_ durumu_2011_subat.pdf

Tuskan, A. A. (2007). Kadın hakları ve yeni medeni kanun [Women's rights and the new civil law]. [Online] Available: http://www.hukuki.net/hukuk/index.php?e=1914

United States of America Federal Glass Ceiling Commission. (1995). Good for business: Making full use of the nation's human capital. Washington, DC: US Government Printing Office.

Willemsen, T. M. (2004). Gender typing of the successful manager-A stereotype reconsidered. Sex Roles Journal. 46. 385-391. 